\title{
Genevieve Taggard: The Hawaiian Background to a Radical Poet
}

\author{
ANNE HAMMOND
}

The Writer Genevieve Taggard (1894-1948) was brought up in Hawai'i. Her life in Honolulu, from 1896 to 1914 , from infancy to early adulthood, loomed large in the development of her consciousness as a lyrical and often radical poet who, although she later became an important figure in mainstream American literature, never lost her deep connection with a culture which established in her both a delight in her experiences of nature and a conviction in the importance of community.

Having achieved early fame for her lyric poetry in the 1920s, at the height of the Depression in New York, she began to write poems that expressed her belief in socialism as a solution to the problems of capitalism. These poems have been heavily criticized by some critics for being overly didactic and propagandistic, and as a result her literary reputation has been on the whole limited to her lyric creations. ${ }^{1}$ When she died in 1948, the McCarthy campaign against communism (through the prosecutions of the House UnAmerican Activities Committee) was accelerating, and any writer tainted by radical affiliations

Dr. Anne Hammond is Visiting Research Fellow at the University of the West of England, Bristol, UK. In 201 I, she was awarded a short term fellowship at the New York Public Library to study the Genevieve Taggard Papers. She is now writing a book-length critical study of Taggard's life and work. She is the author of Ansel Adams: Divine Performance (Yale University Press, 2OO2), and Ansel Adams at Manzanar (Honolulu Academy of Arts, 2006).

The Hawaiian Journal of History, vol. 49 (2015) 
was denounced or ignored. By 1985, her work would be described in the Dictionary of Literary Biography as "now largely forgotten." ${ }^{2}$ The strong social commitment that produced her politically driven poems was largely formed during her childhood in Hawai'i, by the moral and social conscience instilled in her by progressive reformist Christian parents in the mixed-race community of Kalihi. Although she wrote very few poems about Hawaiian subjects during the Depression years, in 1946 she returned to them in her last book titled Origin: Hawaii (1947). Some of those late works, both lyrical and politically charged, represent her determination to create emotionally complex poems that celebrate the human striving for racial and economic equality which she valued in the doctrine of socialism and, eventually, communism.

\section{Hawaiman Beginnings and the Social Motive}

Genevieve Taggard was born in 1894, in Waitsburg, Washington, to schoolteacher parents who took her with them when they emigrated to Hawai' $i$ in 1896 . In 1897 , the Taggards moved to the foot of Kalihi Valley where her father James N. Taggard took up the post of principal of Kalihi Waena School and her mother Alta was employed as a teacher. Kalihi Waena was a public elementary school, founded nine years earlier, with students of many different races and cultures where Taggard's sense of herself as a culturally integrated local person was formed. She and her friends gathered kiawe (algaroba) pods to sell for animal fodder, learned how to catch live minnows, and roamed the shore and the valley (now the route of Likelike Highway, which leads to the Wilson Tunnel through the Ko'olau Range) picking wild guavas, mangoes and bananas.

By 1896 when the Taggards arrived, school attendance for all children from six to fourteen became mandatory in Hawai'i under the Provisional Government. The native population of ethnic Hawaiians was already largely literate in the Hawaiian language, but with the goal of annexation looming the government pushed for universal mastery of English. In the wake of the overthrow of the reigning Queen Lili'uokalani, but before Hawai'i was recognized as a territory of the United States, all workers paid by the Provisional Government (including teachers) were required to sign an oath not to support any 


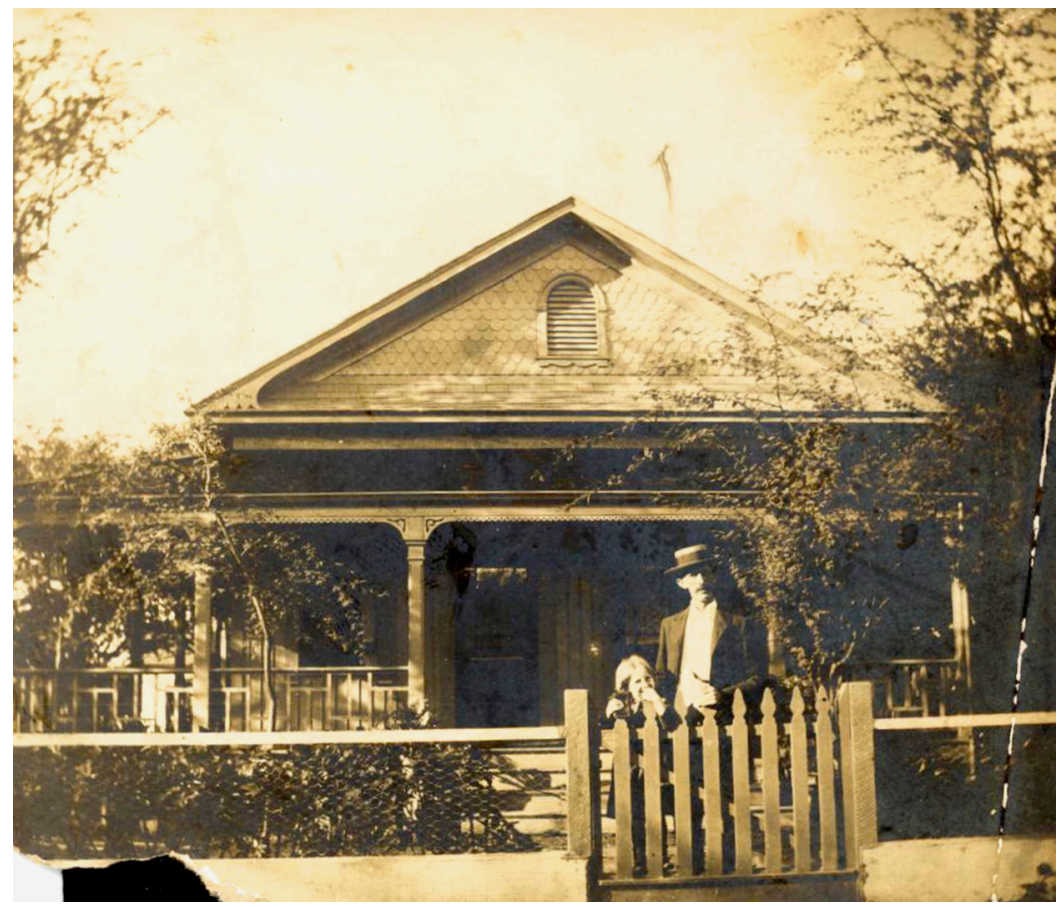

Figure 1. J.N. Taggard and Genevieve Taggard, at their first home in Kalihi, c. 1900. Donald Angus Papers, Special Collections, Hamilton Library, University of Hawai' $i$ at Mānoa.

attempt to reinstate the monarchy. This resulted in a reduction in the numbers of Native Hawaiian teachers (who, naturally, might be unwilling to sign such an oath), and a campaign to encourage white American teachers like Genevieve's parents to emigrate from the mainland, solidifying the power of the haole- [Caucasian] controlled educational system. ${ }^{3}$

In 19o6, Genevieve was enrolled at Punahou Preparatory School, which had been founded in $184^{1}$ for the children of the early Congregational missionaries and was by the turn of the century the preeminent school in Hawai ${ }^{i}$, with high tuition fees which her parents would have struggled to pay. Although there was some degree of racial mixture at Punahou, it was a school for the wealthy upper classes. The yearbook for Genevieve's graduating class shows a number of 
part-Hawaiian and Chinese students: the children of eminent haole who had married Hawaiian women, and families of wealthy Chinese tradesmen. But those with whom Genevieve spent her early childhood out in Kalihi-the children of Hawaiian, Portuguese, Chinese and Japanese plantation workers-did not go there, and the twelveyear-old Genevieve would have understood that she had been lifted out of the throng of the working class into the school for the elite. Fortunate as she was to be there, this may have contributed later (in her first autobiographical writings of the early 1920s) to a feeling of internal conflict she could never fully resolve.

James Taggard's chronic tuberculosis sent the family back to Waitsburg in 1910 when Genevieve was sixteen. He and his wife, by now with three children, were hoping to restore their depleted finances with the repayment of a $\$ 2000$ loan they had made years before to one of James's brothers (an amount worth around $\$ 5$ o,ooo today). Faced with his refusal to honor the debt and nearly destitute, the Taggards were devastated to find themselves in a condition of near servitude, working for James' brother, John (who had become a wealthy landowner and fruit-grower on the strength of their loan) in exchange for rent, living in the hired hand's house, and having to accept church charity. It was an experience that shocked the adolescent Genevieve and established in her a profound realization of class difference and the power relations of money that she never forgot. Some writers have suggested that she came from a bourgeois middle-class backgroundand her parents certainly aspired to that cultural level-but her correspondence and family reminiscences suggest that they struggled financially: in Washington enduring real poverty, and in Hawai'i just managing to make ends meet.

Many years later, in her preface to Origin: Hawaii, Taggard cherished the memory of a verse from the Bible (John 10:10): "I am come that ye might have life and have it more abundantly." "I have never ceased to think," she wrote, "that the text, taken literally, should be the aim of all governments." The deeply ingrained memory of that verse was integral to her experiences in the church to which she and her parents belonged in Honolulu, whose beliefs underpinned Genevieve's social commitment in her adulthood. The Taggards belonged to the Disciples of Christ, an Evangelical sect which grew out of Presbyterianism in America in the 1820 . Their decision to move to 
Hawai' $i$ with the two-year-old Genevieve in 1896 may have been partly motivated by the opening of the first chapel of the Disciples of Christ in Honolulu (on Alakea Street near the corner of King Street) under the Rev. Thomas D. Garvin the previous year. John and Alta Taggard went to Hawai'i not as Congregational Protestant missionaries of the sort that had arrived in the islands eighty years before (who were by this time the land-owning children and grandchildren of those earlier immigrants now comprising a haole elite, a wealthy upper class in Hawai'i's social hierarchy), but as dedicated teachers of modest means who believed in an inclusive Christianity, moral and practical education, and social reform.

Like many of their generation in the 1890 and at the turn of the century, they were progressives who believed in the betterment of society and in democratic social change. The progressive movement, backed by philosophers and economists such as John Dewey and Thorstein Veblen, was in this period calling for government reform

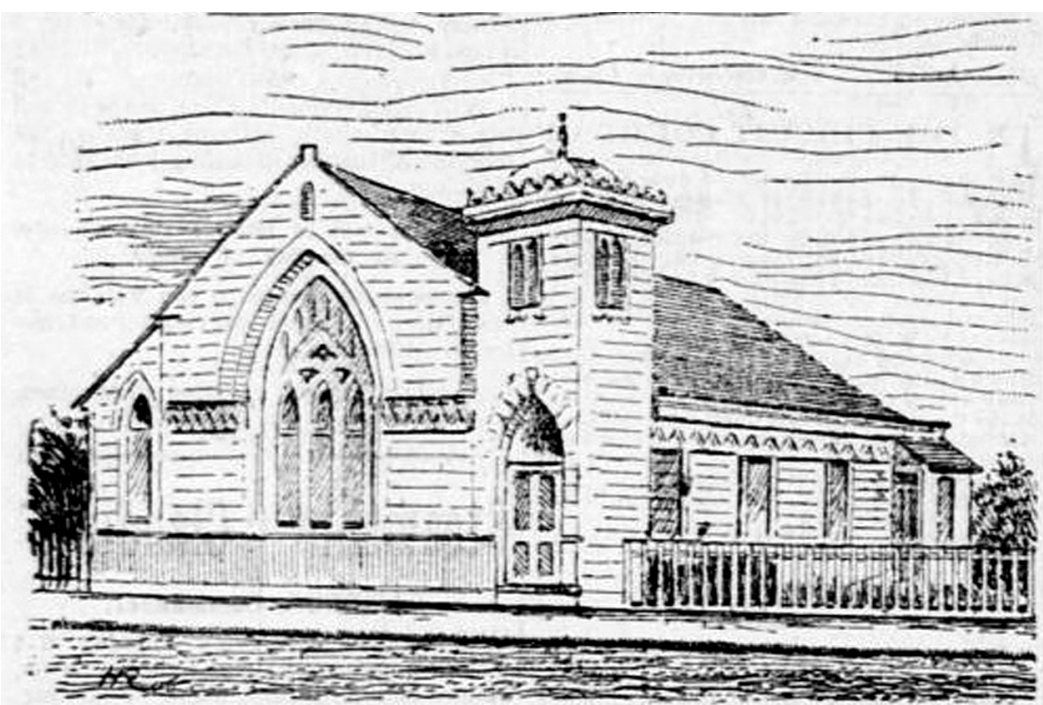

THE NEW TABERNACLE OF THE CHRISTIAN CHURCH WHICH WAS OPENED FOR WORSHIP SUNDAY. (Siketched by the ADVErtiser artist.)

Figure 2. The 'new tabernacle,' Church of the Disciples of Christ, 1895, from the Honolulu Advertiser. 
to solve the problems of labor conflict and urban slums. ${ }^{4}$ The Taggards' desire for social improvement was underpinned by their affiliation with the Disciples of Christ, in which a new social liberalism had developed in the 189 os. In 1894 , one of the church's most respected commentators, James H. Garrison, wrote:

without departing in the least from the spirit and aim of the gospel, ... we would urge upon our ministers the importance of extending practical sympathy and aid to all wise movements: looking to the purification of our political life, the removal of unjust burdens from the shoulders of the oppressed, the enactment of laws for the better protection of life and health of the toiling masses, [and] the settlement of difficulties between labor and capital. ... ${ }^{5}$

Political action, he believed, was the duty of all Christians.

James Taggard's time as principal of Kalihi Waena School coincided with the tenure of Henry S. Townsend as Inspector General of Schools in Hawai'i. Townsend advocated "learning by doing" rather than traditional, passive rote memorization. ${ }^{6}$ His liberal policies very closely followed the educational philosophy of Francis W. Parker, and with the assistance of Board of Education member Emma I. Dillingham (mother of Mary Dillingham Frear, friend of the Taggards) Townsend managed to bring him to Hawai'i, fresh from his new experimental school in Chicago, to speak at the 1898 Hawai'i teachers' summer school. ${ }^{7}$ Parker was a pioneer in the progressive school movement, focusing on the education of the whole child, and experience-based learning with a strong emphasis on language and writing. One of Parker's key principles was "the social motive," the idea that values enhancing the group and community were fundamental to human development. ${ }^{8}$ Freedom of expression was encouraged, but freedom was always kept in balance with responsibility.

In the summer of 1899 , Townsend presided at a conference in Honolulu of the Teachers' Association, which included in the first session a report on the current state of schools on O'ahu by Genevieve's father. John Dewey (a great admirer of Francis Parker, with whom he had worked closely in Chicago) had been invited that summer to speak at the teachers' summer school, and during August and September he gave a series of eight lectures for the University Extension at Honolulu High School (now McKinley High School) on subjects 
of early education and themes of general philosophy. ${ }^{9}$ It is extremely likely that both of Taggard's parents, as new teachers in the public school system, attended these summer schools.

In Dewey's 1897 essay, "My Pedagogical Creed," based on his experience of establishing an experimental school in Chicago, he expressed his conviction that education was the foundation of all social progress and reform. True education was, for Dewey, the gradual adjustment of the individual to social consciousness and social responsibility, enabling the child to conceive of himself from the standpoint of "the welfare of the group." ${ }^{10}$ This concept, which Genevieve may have understood from her parents' attitudes to ethical education (particularly since she taught at Kalihi Waena herself in her last year of high school during her father's illness) was reinforced during her school years at Punahou, under its principal, Arthur Floyd Griffiths, a progressive administrator who entreated the entire student body to learn the causes of poverty and to "take a definite responsibility for the betterment of their own community." 11

Jack London, who visited Hawai'i during the Taggards' residence there, was a socialist, many of whose writings advocated revolutionary change in the existing power structure. His first book to explicitly denounce the evils of capitalism, after his conversion to socialism in 1896, was The People of the Abyss, exposing the desperate poverty of the English urban slums. Upton Sinclair called him "one of the great revolutionary figures" in history. He became the most popular writer of the working class, and even a decade after his death he was acknowledged by the radical magazine The New Masses as "a real proletarian writer." 12

London's writings have become less popular in the course of the twentieth century because of his attachment to an idea of white supremacy, through the Nietzchean "superman," which emerged in his adventure stories. ${ }^{13}$ Ironically, it was the success of Call of the Wild that brought requests for his writings from the socialist press, and resulted in the publication of essays such as "The Class Struggle" in the New York Independent (5 November 1903) and "The Scab" in the Atlantic Monthly (January 1904). Between 1905 and 1907, London became a national spokesman for the socialist movement, lecturing for the Intercollegiate Socialist Society, raising money for labor causes, and writing essays and stories to convey the revolutionary 
socialist message to the American public, culminating in his book The Iron Heel in 1908.

The year after Genevieve entered Punahou Preparatory School, Jack London and his wife Charmian made the first of three visits to Hawai' $i$ in 1907 , staying for eight months in a rented house on the beach at what is now Pearl Harbor. The stories he wrote, based on his experiences there, were collected in The House of Pride and Other Tales of Hawaii, published in 1912, and were strongly informed by his socialist beliefs, which often spurred him to denunciations of race and class oppression. "Koolau the Leper," published in the liberal Portland journal The Pacific Monthly in December 19o9, leveled accusations against the white capitalist ruling class of Hawai'i for the importation of Chinese workers infected with leprosy and for forcibly displacing the (mostly Native Hawaiian) sufferers of the disease to the island of Moloka' $i$ and expropriating their land.

Even if Genevieve was prohibited, as she claimed in her 1927 memoir "Poet out of Pioneer," from reading anything but the Bible at home in her childhood, it is likely that she would have been exposed to at least London's The House of Pride in the library at Punahou (then called Oahu College) where she attended high school from 1912 until 1914 after the family's return from Washington, and where she made considerable literary contributions herself to the school magazine. ${ }^{14}$ She published poems and short stories in Punahou's yearbook The Oahuan and served as editor-in-chief during her senior year. The school library was a valuable resource for such a young literary hopeful, with a major donation having been made in 1913 by the

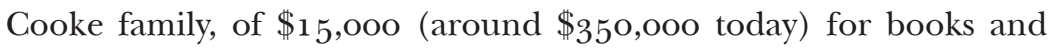
equipment.

Taggard's awareness of Jack London as, in his time, a well-known interpreter of Hawaiian life, and as a socialist, would have been magnified by the memorial issue of Overland Monthly (the preeminent literary magazine of California) upon his death in 1916, when the family was in Berkeley. Her own short story, "Lani," had appeared in its pages in November 1915 , and she must have been interested to see the contents of this special "Jack London Edition," including a biographical study by George Wharton James, a poem about him by George Sterling, a long article featuring his conversion to socialism, and an essay about London's visit to Hawai' 'i. By the time The Makaloa 
Mat, a second collection of London's stories about the islands, was posthumously published in 1919-the year Taggard graduated from college-she no doubt realized that her life experiences in Hawai' $i$ could provide equally fertile material for her own prose and poetry, which she began writing around that time and through the early 'twenties.

One of the first things she published when she arrived in New York in 1920 was a series for the Christian Science Monitor of short prose pieces on Hawaiian plants, including the kiawe tree, banana, papaya, banyan, monkey pod, coconut palm, and lantana. ${ }^{15}$ Taggard's item on the lantana, in December 1920, clearly signals its debt to an article by Jack London printed just before his death in The Cosmopolitan Magazine. In Taggard's unpublished notes for her text we hear London's own story of the plant arriving in a little pot and placed in a missionary greenhouse, and the efforts of cattle ranchers later to "grub it out" (the very words used by London) when it became invasive and a serious pest all over the islands, as so many alien species did. London even made it a metaphor for white imperialist encroachment: "Like the invading white who dispossessed the native Hawaiians of their land, so did the lantana to the native vegetation." 16 This is perhaps obliquely alluded to in Taggard's title "Land-Tanna," along with her reference to what was then London's most famous publication, when she described the lantana as "a plant that heard the call of the wild." But whereas London's anti-colonialism is explicit in his version, Taggard's is an implicit association with London's socialism with which she identified herself during her student years at Berkeley. "In those days," she later wrote, "Frank Norris and Jack London were still heard of as friends of friends. The great city of San Francisco taught me a good deal that I needed to know." 17

It was natural that Genevieve's parents would hope for a university education for her, and Hawai'i in that period offered no prospects. The College of Agricultural and Mechanical Arts of the Territory of Hawai'i, founded in 1907, would not add a College of Arts and Sciences until 1920. When Genevieve was accepted by the University of California in 1914, the family moved to Berkeley and supported themselves by running a boarding house next to the campus on Channing Way. Her university education during World War I established her socialist beliefs, confirmed in the light of the Russian Revolution 
in 1917 . In that year, she became the editor of The Occident (the university's literary magazine), where some of her own prose and poetry was published between 1915 and 1918, much of which-including the short story "Lani," and the poems "The Mongoose," "Hawaiian Sonnet," and "Maui of Haleakala"-was inspired by her upbringing in the islands. ${ }^{18}$

Another event that may have focused Taggard's consciousness of her Hawaiian cultural identity was the opening of the Panama Pacific International Exposition in San Francisco in 1915, which generated in the continental U.S. an explosion of popular interest in Hawai'i and Hawaiian music, just months after the Taggard family's arrival in the Bay Area. As early as spring 1912, the Honolulu cultural journal Paradise of the Pacific was already reporting on preparations for the fair and advance publicity was appearing in Mid-Pacific Magazine from the fall of 1913. On July 7, 1914, a year before it opened, a groundbreaking ceremony was held for the Hawai'i Pavilion to great public relations effect, even including lei sellers, a "moving picture entertainment showing Hawaiian scenes," and performances by the Ernest Ka'ai Quartet. ${ }^{19}$

In November 1919, after her graduation, when Taggard was still living in Berkeley and working for a San Francisco daily newspaper, she sent some poems on Hawaiian themes to Poetry Magazine; one of them, "From the Frail Sea" was accepted for publication in June 1920. She summarized her Hawaiian years to the editor, Harriet Monroe:

"I went to the Hawaiian Islands when I was two years old and lived there until I came to college. My mother and father were teachers on the plantations, so I lived with the Hawaiians and came to know many intimate things about them. I heard their stories by word of mouth, from the old people. My greatest desire is to save the poetry of their temperaments, and their traditions, from being lost with them." ${ }^{20}$

Her wish to preserve "the poetry of the temperaments" of Native Hawaiians somewhat parallels the impulse of photographer Edward Curtis in his attempt to depict Native Americans in traditional garments unique to their cultures in The North American Indian (19071930). By the turn of the century, the popular image of the Native American was limited to the exotic but superficial entertainment of the wild west show. Public hula performances on tour, such as those 


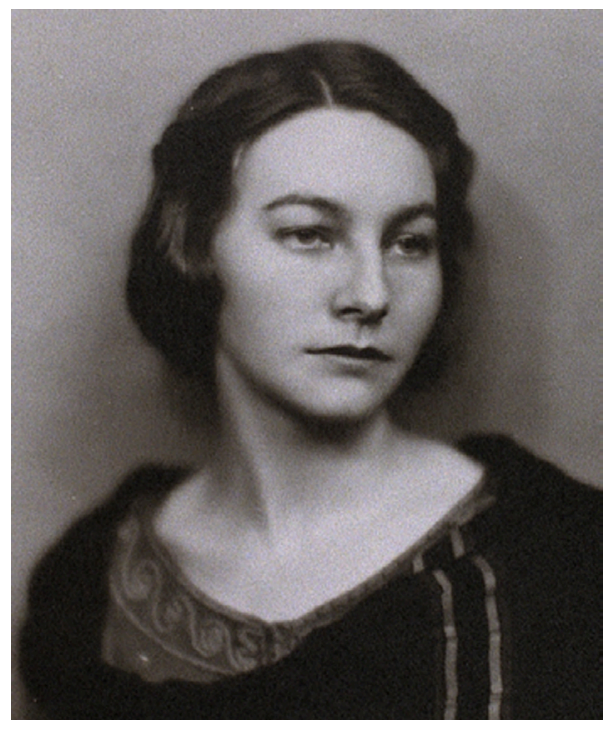

Figure 3. Portrait of Genevieve Taggard, c. 1919, from The California Monthly (October 1927).

staged for the Pan-Pacific Expo, represented the equivalent for the ethnic Hawaiian, a commercialized impression Taggard will have seen as inauthentic to her own experience of the people, and one she may have hoped to correct or revise through her poetry.

But it would be quite a few years before a mature political awareness enabled her to write about Hawai'i in a critique of the prevailing popular image of Hawaiians and their history. Her high school and early undergraduate literary education had emphasized the work of the romantic poets of the nineteenth century. In "Skull Song," first published in The Occident in 1918 and included in her first book of poems on Hawai'i, Hawaiian Hilltop (1923), her early lyrical style embraces a popular poetic form of the turn of the century, the ballad: "The skin of the sea was thick, to-night,/ And the tone of the sea was dull; / When I found by the edge of the sullen sea/ The half of a sea-god's skull."

The form of the poem, with its stanzas of internally rhyming quatrains and phrase repetitions, is reminiscent of Robert Louis Stevenson's Penny Whistles or A Child's Garden of Verses and Kipling's The Seven Seas, and derives its narrative from the storytelling traditions of the previous century. Taggard was well acquainted with Stevenson's work- 


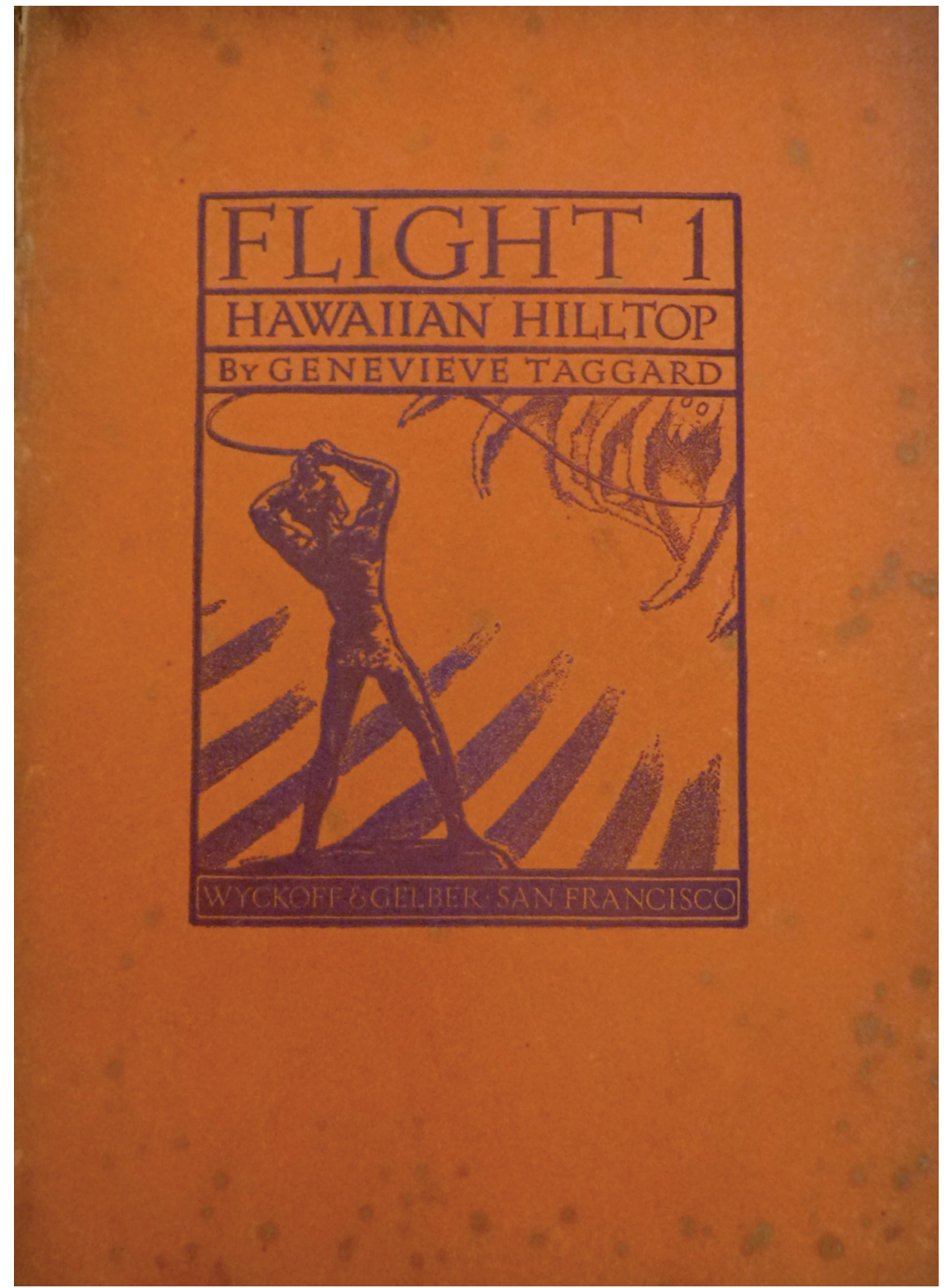

Figure 4. Cover of Hawaiian Hilltop, published in 1923. Beinecke Library, Yale University. 
his poem "To Princess Kaiulani” was reprinted upon Ka'iulani's death in 1899 in the teaching magazine used by Taggard's parents, Hawaii's Young People, and she referred to it in the introduction to her own 1920 poem about the Hawaiian princess. ${ }^{21}$ But beyond the romantic mythological tone of "Skull Song," the imagery (possibly stimulated by her undergraduate exposure to the works of Sigmund Freud) of the "half of a sea-god's skull" and "half of a sea-god's tail" suggests the separation of the psychological from the physical existence, in "the sinister sea" of the chaotic and dis-integrated life of modern man. It represents, perhaps, the split consciousness of the writer, and the mortal part of the skull safely buried at the end of the poem may reflect the poet's conscious struggle to suppress nostalgic memories of her childhood.

But at the same time that she was submitting work to Poetry, she also had five poems on Hawaiian subjects accepted by a New York leftist magazine, The Liberator, the radical journal that succeeded The Masses. ${ }^{22}$ She was now politically engaged and looking to the future. Taggard had met Max Eastman, socialist editor of The Liberator and former editor of The Masses, on his lecture tour of California in 1919 and it was he who encouraged her to move to New York and became her mentor and lover when she did.

Arriving in New York in 1920, she took a job in the publishing offices of B.W. Huebsch, working on the newly founded radical magazine The Freeman, with content similar to the Nation and the New Republic, and reviewed poetry books for its literary editor Van Wyck Brooks. She married that year, and also founded a literary magazine herself with a group of her peers, The Measure, which ran until 1926. In 1921 , she and her husband, the writer Robert Wolf, with their new baby Marcia, went to California for a year where she taught poetry at Berkeley and helped edit an anthology of works by Pacific coast writers. She also finished her first book of poems, For Eager Lovers, published in 1922. The following year, shortly after she returned to the East Coast, her second volume of poems, Hawaiian Hilltop, was published by Wyckoff and Gelber in San Francisco and printed by the Grabhorn Press, but it was not widely distributed and received little critical notice.

In 1929, after publishing two more books of poems, she found a job teaching English at Mt. Holyoke, a women's liberal arts college in 
Massachusetts, and in the spirit of her parents' dedication to progressive education she later taught at two other experimental colleges: Bennington College in Vermont (1932-34) and Sarah Lawrence College in New York $\left(1935^{-46}\right)$. In 1930, she wrote the first scholarly biography of Emily Dickinson, and in the same year published an anthology of metaphysical poetry, Circumference. In 1934, after divorcing her first husband (who was committed to a mental institution) Taggard married again, to Kenneth Durant, director of the U.S. office of TASS (the Russian news agency) in New York, and in the following years the evidence in her poems of a fervent socialist commitment rose to a new level. They had their honeymoon in Russia in the summer of 1936, and Taggard began on her most radical poems, collected in Calling Western Union, published in that year.

\section{The Cost of Imperialism}

Although she was writing revolutionary poems as early as 1919, it wasn't until the mid-1920s that Taggard began to find her political voice. ${ }^{23}$ In 1924, she published a memoir of her childhood, "A Haole Scrapbook," in the Bookman. ${ }^{24}$ The pretext for writing it is offered in the report of her acquaintance with a man who had "spent a few weeks in Hawaii and knew more useful things about its geography, commerce, politics, industry, anthropology and geology" than she did, whereas her personal memories of the place of her childhood were of her peer group, local characters, and her intimate relation to the natural environment. Whoever this "traveller" was, he represents a device for the expression of her developing awareness of the political history of the kingdom, overthrow, and territory of Hawai'i and the social injustices perpetrated on the peoples of Hawai' $i$ by the forces of American capitalism. By assigning to herself the term haole (the original meaning of which is "foreigner") in her title, Taggard was now accepting the role of outsider, seeing in a more critical light the formative culture to which she would never return.

In the text of her memoir, she feigns disinterest in the traveller's talk of Hawai'i's sugar and pineapple industries. But her story of the communitarian life of island children, availing themselves freely of the fruits of forest and shore, soon turns to their introduction to capitalism, and its underlying effects of greed and exploitation, as 
they carry bags of algaroba beans to sell for loose change to the "rich man" who keeps stables of horses for tourists. Here, childhood reminiscence quietly takes the shape of economic allegory. As her most admired young friend, the "native" boy John Frank, stands on a rock at the water's edge where generations of his ancestors fished, she remarks that it is now "on a white man's estate." Her racial separateness and implied cultural complicity is keenly felt, within this admission of American acquisition of Hawaiian lands, when he says regretfully, "Too bad you gotta be haole." She admits to thinking so, herself, for the rest of her life. ${ }^{25}$

In 1925, Taggard compiled an anthology of poetry, May Days, from the radical magazines Masses (1912-1917) and Liberator (19181924). In her introduction, she explored the problems of art and propaganda in these two revolutionary journals, suggesting that their great social and creative achievements finally came to an end because the artists were frightened of revolution and the propagandists gave artists an impossible task to perform, even quoting Leon Trotsky from his book Literature and Revolution, recently translated into English. She also announced that she would donate all her royalties to the cause of the International Workers' Aid, a relief agency responding to Lenin's call for humanitarian assistance in the face of famine in the Volga region in the early $1920 .^{26}$

In the same year, Dollar Diplomacy: A Study in American Imperialism, by Scott Nearing and Joseph Freeman, was published by her former employer, B.W. Huebsch. Living in New York in this period, she would have been alerted to it by reviews in the liberal press. A discussion over three pages in this book outlines the imperialist motives behind the annexation of Hawai'i, based on competition for the U.S. sugar market and the strategic importance of a potential naval base at the onset of the Spanish-American war in 1898 . Taggard voiced her response in the same year to the social and economic injustices committed against the people of Hawai'i in this poem:

\section{For Hawaii Brought Low}

Let me be voice for that proud, lovely race,

Let me be words for them, who are so mute;

Let me be lips to tell the hushed disgrace

Of these, my people. Let my sharp words shoot 
Cutting to death the righteous, scheming brood

Of these, my people who have plundered them.

Rude let me be, who are their blood, as rude

They were who broke this flowering stem.

For them, sweet singers, let me not be dumb

In this, their silent day, when they lie down

Simple and sad, aware that they have come

To the death that brooded in my people's frown.

If I can tell of them, so they be heard

My own small griefs may go without a word. ${ }^{27}$

On the surface, this sonnet-unusual in the ferocity of its political protest-seems to be both an elegy for the Native Hawaiians, and an indictment of the American oligarchy that robbed them, "plundered them," of their birthright. But it contains an ambiguity, which allows her in the first four lines to apparently identify in the phrase "these my people" with the victims of oppression, and in the next two to admit her complicity with their oppressors.

In 1899, the Inspector General of Schools, H.S. Townsend, under whom Genevieve's parents worked, presented a paper at the National Education Association meeting in Los Angeles, in which he expressed the special cultural situation in which educators in Hawai'i found themselves: "The civilization which the aggressive race had developed and in which it has been trained, based upon an assumption of universal selfishness, has precipitated a struggle in which the passive Hawaiian race is at a great disadvantage." ${ }^{28}$ Rampant capitalism in the wake of imperialist colonization had fostered values foreign to the communitarian and non-competitive Hawaiian way of life, the "flowering stem" that Taggard describes as broken.

Although she would have known that by 1920 the Native Hawaiian population was almost literally decimated from its size in $185^{\circ}$, there is another historical factor that may have stimulated her to write this poem. In 1924 (the year before she wrote it), striking sugar plantation laborers on the island of Kaua'i were violently confronted by police, resulting in the deaths of about twenty people, mostly workers. What suggests this event may have some bearing on the poem is her sentence, "Let my sharp words shoot/ Cutting to death the righteous, scheming brood...." The overall subject is the political and social 
decline of the Native Hawaiian people, but it seems strongly colored by the Kaua'i sugar strike massacre. Perhaps for Taggard the racial origin of the striking workers, mostly Filipinos, was less important than their identity generally as peoples of Hawai'i, exploited by the same white ruling class as the Native Hawaiians. As this tragedy was reported by the Associated Press, she would certainly have read about it in New York.

In 1924, Clifford Gessler, a Chicago journalist who had gone to Hawai'i to work for the Honolulu Advertiser in 1921, published Slants, his book of poems about Hawai'i. Having seen Taggard's Hawaiian poems in Poetry magazine, he wrote to her the following year to ask if she would review his book there. In the end, the journal decided to print Margery Swett's review of Gessler's book, but it was printed alongside a review of Taggard's own book, Hawaiian Hilltop. The question of whether Taggard was aware by the early 1940s of the political situation in Hawai' $i$, with regard to the communist-affiliated labor unions, is answered conclusively by Gessler's 1942 book, Hawaii: Isles of Enchantment, in which he quoted in full Taggard's poem "To a Brown Face" from Hawaiian Hilltop. The poem suggests an inner conflict: the poet is "unwillingly/ To that far kingdom subject," and at the same time she is-along with the wind, and "all the waves of earth" (in short, all the elements of nature)-inexorably drawn back to it in her memory. But a further chapter in Gessler's book also describes sympathetically the harsh working conditions of plantation laborers, and reports on the Japanese and Filipino sugar plantation strikes of the 1920 , including strike-breaking and worker intimidation, and the Kaua'i massacre of $1924 \cdot{ }^{29}$

In fact, Taggard would have known all too well the ill effects caused to the culture and people of Hawai' $i$ by the early 193os. In 1934, a pamphlet written by Samuel Weinman, Hawaii: A Story of Imperialist Plunder, was published by Alexander Trachtenberg, whose International Publishers effectively constituted the publishing arm of the American Communist Party from the 1920 on onward, and held significant power within the editorial group of the radical magazine New Masses, where Taggard was a contributing editor during the 193 os. $^{30}$ She may have been shocked to read it, but cannot have been totally surprised by the content, an explosion of Marxist outrage at the crimes perpetrated against the land and peoples of Hawai'i through 
exploitation by the sugar barons. The rosy tourist view painted by the Hawaiian publicity machine, he argued, hid from the public the conditions of slavery on the plantations and concealed military preparations for another capitalist war.

Whether or not Taggard read Weinman's pamphlet, she could not have avoided seeing his June 1934 review in New Masses of Ruth McKee's novel about the lives of missionaries in Hawai'i. Weinman condemned McKee's book for failing to reveal the evil perpetrated by the missionary colonization of the islands, bringing "forced labor, syphilis, and whisky to Hawaii, leading to the annihilation of the native population ... from 200,000 in 1820 to 22,230 in 1932." ${ }^{11} \mathrm{He}$ declared that as the missionaries became merchants and sugar planters, and with land taken from the native population, they imposed a two-crop economy of sugar and pineapple. The self-sufficiency of local agriculture was thereby lost, with the wealthy ruling class importing foods from the mainland, and the natives living mainly on a diet of rice and working in poor conditions for slave wages on the plantations. "The missionaries and their heirs," he wrote, "have ground hundreds of millions of dollars in super-profits out of the plantation toilers. Plantation strikes have been crushed in blood." ${ }^{2}$ This attitude of anti-capitalist indignation was reiterated by another voice which Taggard could not have ignored in New Masses, Walker Winslow, whose poem "God's a Haole" appeared a few months later in October: "God's a haole/with his hands in his pockets, /Jingling coins. ... Plantation angels drip/ Molasses into his palms;/And God, the alchemist, / Drips coins into a vault."

In 1942, Taggard reviewed for the New Masses a book by Blake Clark about the $194^{1}$ attack on Pearl Harbor. The United States' lack of preparation for this attack, she suggested, was due to an eastern bias in the American consciousness, looking to New York and even to Europe rather than addressing the social and political problems in Asia and the Pacific. Another cause of that shortsightedness was that Americans had been "content to take the Chamber of Commerce version of Hawaii, and the Tourist Trade version, and the Hollywood version," which was to her "blind and degrading." ${ }^{33}$ It is no wonder, then, that the invitation she received in the mid-thirties from a publicity photo-agency for the tourist industry, the Pan-Pacific Press 
Bureau, to once again visit Hawai'i and write a promotional piece about the islands was ignored.

In her autobiographical essay in the Yale Review of September 1945, "Plenty Pilikia," Taggard's knowledge of the political and commercial forces at work in the Pacific is now explained through the historical record of exploitation and imperialism. She presents this revelation through quotations from the pages of the Hawai'i public schools teaching magazine, Hawaii's Young People, edited by Osmer Abbott in Lahaina through 1899, which she comes across in her parents' library. Here, she says, she learned the myths of the "hero Maui and the goddess Pele" even before Demeter and Prometheus. But the news events reported by Abbott and highlighted by Taggard relate to the balance of power in the Pacific, impending war, and warnings of fascist politics and racism in other parts of the world. These include notices about Aguinaldo (a leader in the Philippines 1896 revolution); the "fighting in Samoa" (the second Samoan Civil War between two imperialist powers, the U.S. and Germany); the dethroning of the Chinese emperor, apparently for affecting western habits; the Dreyfus affair (by then an example of anti-Semitic prejudice); the U.S. saber-rattling at the start of the Spanish-American War; the attempt on the part of the Hawaiian Sugar Planters' Association to reduce the perceived threat of the so-called "yellow peril" in the large numbers of Japanese on the plantations by introducing Portuguese workers from Madeira and the Azores; and the takeover of large portions of the Honolulu waterfront by the United States government. ${ }^{34}$

Finally, she focuses on the raising of the American flag at 'Iolani Palace on August 8, 1898, which she witnessed as a child of four. She recalls a dignified assemblage of Hawaiians, all dressed in white, weeping aloud as Berger's Royal Hawaiian Band played "Hawai'i Pono“ī" (the national anthem of the Kingdom of Hawai"i, composed by King David Kalākaua in 1874). This makes of her story a personal realization of the Hawaiian peoples as victims of American imperialism (by 1899, the three best harbors in Oceania-in Honolulu, in Pago Pago and in Manila-were under U.S. control) and her examples from Abbott also expose an American paranoia fuelled by race prejudice against Asia which, she suggests, was one of the main causes of World War II. In her memoir, she embeds these documents of historical and 
political events-imperialism and implied race prejudice-within the personal and tactile memories of her childhood: of the schoolroom and church, banyan roots, the red earth, the sea, the crabs and coconuts, just as she would integrate them in her Hawaiian poems of this later period.

In 1944, the photographer Paul Strand (whom Taggard had known since the mid-thirties through the League of American Writers, and as a key figure in Frontier Films) renewed his friendship with Taggard and her husband Kenneth Durant, and took his wife Virginia with him on visits to their farmhouse in Vermont. Virginia, an actress and budding journalist, had joined the cast in 1946 of the travelling production of the play "Blythe Spirit" for the USO, which would take her across the Pacific. On the return voyage, the ship stopped in Hawai' $i$, where Virginia interviewed union leaders for an article she was writing. Taggard must have shared with Virginia her knowledge of the emerging labor unions there because in November 1946, when Virginia returned, she sent Genevieve her thanks and copies of snapshots she had taken of the leaders of the ILWU (International Longshore and Warehouse Union) in Honolulu. ${ }^{35}$

When the territorial government of Hawai' $i$ was established in 1900, contract-labor became illegal, and plantation laborers began to call for higher wages and better conditions. A series of labor disputes erupted over the next few years (in 1905, 1906 and 1909); in 1920 Japanese and Filipino plantation workers all over $\mathrm{O}$ 'ahu went out on strike. But the labor union movement in Hawai'i really took root in 1935 with the arrival of Jack Hall, who along with Bill Bailey prepared the ground for the Hawai' $i$ chapter of the Communist Party U.S.A. in $1937 .{ }^{36}$ During the war, martial law was declared in Hawai' $i$ (December $194^{1}$ to October 1944), and all labor organizing was prohibited under wartime security restrictions. When civilian law returned to the islands, the ILWU launched a campaign to unionize the plantations. By June 1946, their huge membership drive succeeded in enrolling 20 ,ooo of the approximately 24,000 sugar workers-just a couple of months before the arrival of Taggard's friend Virginia Stevens. When Virginia returned in August, Paul Strand wrote to Taggard that she was hard at work on her article about the labor movement in Hawai ' $i$ where, he reported to Taggard, apparently "vast changes" had taken place in recent years. ${ }^{37}$ 


\section{A Hawaitan Origin on the Mind's Horizon}

The greatest proportions of poems based on Taggard's upbringing in Hawai'i are in her 1923 book, Hawaiian Hilltop, and her final book, Origin: Hawaii (although her very first book, For Eager Lovers also includes half a dozen Hawai'i-related poems). Although she wrote fewer poems about Hawai' $i$ in her most politicized period in the mid193 os, even in Calling Western Union (1936) her long preface "Hawaii, Washington, Vermont" foregrounds her Hawaiian childhood. In a couple of her mid-career books, the poem "Try Tropic for Your Ills" survives as a Hawaiian reference and reminder. In her book of 1942, Long View, her memories of Hawai 'i surface again briefly in her prose piece "Notes on Writing Words for Music," in memories of her own musical background in Honolulu. In the biographical statement she provided that year for Stanley Kunitz's Twentieth Century American Authors she indicated that she was working on a history of her parents' lives in Hawai'i; perhaps this and the death of her sister in 1943 fostered a desire to at last reclaim that earlier identification with place and people that had formed her early sensibility and consciousness.

In 1947, Genevieve Taggard's last book of poems, Origin: Hawaii, was published by Donald Angus in Honolulu. The suggestion for the book had come from Angus himself, a Honolulu art collector whose mother had taught at Kalihi Waena School where Taggard's father had been the principal at the turn of the century. Angus renewed his acquaintance with Taggard in Mallorca, where she was supported by a Guggenheim award in 1931, and years later at the end of World War II, knowing how important the islands had been to her values and outlook, he wrote asking if she would be interested in collecting together and publishing the poems about Hawai'i she had written in the early 1920s. She agreed to work with Angus, but rather than simply re-issue the contents of the earlier book, she decided to make a new selection. ${ }^{38}$

The renewal of her acquaintance with Angus by correspondence at the end of the war clearly opened her to the possibilities of reengaging through her poetry with a store of memories of her Hawaiian life that had lain dormant for years. He wrote to her in May 1946 encouraging her to write about the smells of the land and flora he found so true of the place: 
In the hills the earth exudes a smell of its own. Pele's red earth with eons of rotted tropical forest growth leaves ... gives off a smell that I always associate with a tramp in the woods on Tantalus, the Waianae range, the Manoa Valley trail.

On board ship returning to the islands from San Francisco, he told her, he could smell the flowers "twelve hours out of Honolulu." Hoping to encourage her to create some new work, but not wishing to impose his ideas too literally, he insisted it was just a suggestion. ${ }^{39}$

It does however appear to have borne fruit in Taggard's poem "The Luau," in which the images, smells, sounds and tastes of an "old communion," the innocence of a Hawaiian childhood, rise up in her memory: ${ }^{40}$

\section{The Luau}

Odor of algarroba, lure of release.

The smell of red lehua and the crisp scent of maile...

These words and images will help you after a little.

Hypnotic words emerge and bloom in the mind,

Anaesthetic names... Dry buzz of bees

Who make a honey eaten at early breakfast

From a comb like a broken coral ...

Do dreams foretell the honey? Break the spell.

So I come home in the valley of Kalihi,

My bare feet on hard earth, hibiscus with stamen-tongue

Twirled in my fingers like a paper wind-mill,

A wheel of color, crimson, the petals large,

Kiss of the petal, tactile, light, intense...

Now I am back again. I can touch the children:

My human race, in whom was a human dwelling,

Whose names are all the races_of one skin.

For so our games ran tacit, without blur.

What brings me back with giant steps to them?

What was the feast that woke this fabulous thirst?

What was the summer fruit we found and ate

Boldly, with the children of Adam? 
A game and a daily search

In the harvest of trees. We played a parable.

We possessed a valley, devoured the juicy, dense

Jewels of appetite hung in fresco sweeps,

In garlands and in fountains toward the sea.

Mangoes of golden flesh, with turpentine

Peel and odor. Cut plums of inky stain

And the pucker of persimmons. Dates to be got

By stepping up a tree-trunk. Coconuts

With custard centres. Rose and custard apple,

Eugenia, pink, lemon and little orange,

Guava seedy and tart, and the hidden poha,

And the sacklike fig, to be ripped, to be seen, to be tasted.

How rasping sweet the suck of sugar-cane,-

Papaya and banana taken for granted.

With giant steps, in sleep and troubled pain

I return to the fabulous feast, the old communion,

With bodiless hunger and thirst. Why have I come

Away from the adult world where race is war?

Here we are dipping and passing the calabash

In the ceremony of friends; I also;

But in frenzy and pain distort

The simple need, knowing how blood is shed:

To sit together

Drinking the blue ocean, eating the sun

Like a fruit. . .

The "summer fruit we ate boldly" - especially in a place without clear seasonal distinctions-symbolizes the ripening of childhood and youth, and the fruit of the Tree of the Knowledge of Good and Evil. In their fruit-laden valley, these children of "many races" and "one skin" played the "parable" of the Garden of Eden. But as "children of Adam" they also unwittingly embodied Cain and Abel, and the origin of strife and war in the Christian creation story.

The fragrance of maile, the feeling of going barefoot, the taste of mangoes and guavas present an idyllic counterpart to the painful consciousness of "the adult world where race is war"; the knowledge of 
"how blood is shed" makes the reality of that precious life of the senses seem an enchantment, a spell which is broken by knowledge of the inhumanity of nation pitted against nation. Faced with the cruelties and bloodshed of war, the basic values of life symbolized in the innocence and carefree existence of the child in nature become dehumanized. In her religious cultural poem Taggard presents the $l \bar{u}^{\prime} a u$ [feast] experienced with her childhood friends as a symbol of the perfect state of communal sharing of the bounty of nature equally among all people, the social and political ideal which reflects her communist belief in this later period.

Origin: Hawaii comes after nearly fifteen years of Taggard's effort in her own books and in the radical press to integrate her fundamental lyricism with an active ethical consciousness, within her own identity as a revolutionary writer. It is perceptible particularly in poems like "Pacific":" 41

\section{Pacific}

This child went forth to the grace-abounding sea.

I was that child, that child, in memory, me.

The sea was always dancing, never dull.

And every day the blue sea, tangible,

Swept and sustained and rinsed, with the taste of salt

Its children without hurt, in deep cobalt.

To swim was to sink and be captured, taken

Through solid depths and surface dimple-shine

To the leaping edge where the instant's foam was seething.

Except near reefs where we were knocked and shaken

Until our chests were taut with inheld breathing

Fear rarely tainted that water, vast and benign.

Armed forces suffer there today-they hate

Its vasts, its depth, its sharks, its color even.

It and the enemy are both cruel and great.

Innocence is lost that called it heaven.

Their curses, their stoic quiet, taint its sweep.

And history will surely call it deep.

May the brown nations of its islands have

The joy we captured from its colored wave. 
And confidence return, and children swim.

May the lore of the sea enchant again, the rim

Still be the edge of the primitive element we

Rose from, returned to and lived by: the sea.

Bringing together in a single line the near-quote from Whitman ("a child went forth," from Leaves of Grass) and the biblical phrase, "grace abounding" from John Bunyan (Pilgrim's Progress), she unites the great democratic poet with a writer of deep religious faith-and the sea is characterized as a reflection of heaven itself. Like the universe in the innocence of childhood, the sea is maternally benign with an embrace of pure unity and wellbeing. But in wartime, when innocence is lost, it turns into a battlefield of racial and economic strife-and the deepest of graveyards. The poet yearns for a return to a racially inclusive life with "the brown nations of its islands," and the return of confidence in the shared cultural experience, and the good life, that the sea represented to her in her youth.

One aspect of her correspondence with Angus over Origin: Hawaii shows that Taggard's political principles extended even to the production and marketing of her book. In October 1946, with most of the material in hand, Angus wrote that he had spoken to a literary agent in Honolulu, hoping to attract the interest of an East Coast publisher to secure greater national distribution, and thereby greater income from sales, than he would be able to effect from Hawai'i. Her response was swift and uncompromising:

I proceeded on your original impulse-which was-why not put into one group the poems written about this place, and sell them at a reasonable price to people who do or do not understand and cherish the place. I am interested in neither fame nor money. Today these two things represent all that is cheap and disgusting in the world. I am interested in poetry, people (readers) and in a fuller culture... This was a labor of love on your part and mine. If it isn't that, it's nothing. ${ }^{42}$

That labor of love represented the convergence of two deep and vital streams of Taggard's artistic formation. Her conviction of the need for social equality, beginning in her religious upbringing in Honolulu and the social-reformist example of her parents, would eventually lead her to socialism and, later, communism. Although she may have later learned, to her shame, of the political agenda behind 
the campaign of the haole ruling elite in Honolulu to reinforce their power by hiring more teachers like her parents from the U.S. in the post-overthrow period in Hawai 'i, her commitment to social improvement was inherited from James and Alta, to whom Origin: Hawaii is dedicated. If in her own lifetime she came to believe that the only way these good social outcomes could be fully realized would be through revolution, rather than reform, this belief was underpinned in her poetry by the physical and social experiences of her Hawaiian childhood.

A year or so before she died, Taggard wrote to her daughter, Marcia, about the Hawai'i she remembered: "It was a fine, gracious, clean, breezy clear dancing sort of world and I was too young to see what pain and evil were there.... Later, I learned about the sugar planters." ${ }^{43}$ Around the same time, a birthday letter to Genevieve from her mother Alta included the statement: "I think each and every one should make the world a little better because of his having lived." ${ }^{44}$ In the poems of Origin: Hawaii, Taggard demonstrated both her dedication to her mother's idealism, and her desire to bring the beauty of her beloved home to the service of political awareness and social responsibility.

\section{Bibliographic Note}

Genevieve Taggard published two books of poems about Hawai'i: Hawaiian Hilltop (San Francisco: Wyckoff and Gelber, 1923) and Origin: Hawaii (Honolulu: Donald Angus, 1947). She also wrote three autobiographical pieces about her early years in Hawai'i: "A Haole Scrapbook" (Chapters from Unwritten Autobiographies), Bookman (June 1924) 391-99; "Poet out of Pioneer," The Nation (19 January 1927) 63-64; and "Plenty Pilikia," Yale Review 35:1 (September 1945) $4^{8-60}$.

\section{Notes}

I am very grateful to Lynn Ann Davis, of Special Collections, Hamilton Library, University of Hawai'i at Mānoa, for arranging access to the Donald Angus Papers. I owe a debt of gratitude to the New York Public Library, for a short-term fellowship in 2011 to study the Genevieve Taggard Papers, and to the librarians of Dartmouth College Library which holds another important collection of Taggard's 
papers. I am also grateful to scholars of Hawaiian history and the labor movement in Hawai' $i$, and to Dr. Craig Howes, for bringing so many of them to my attention.

${ }^{1}$ See James Daly, "Sincerity is not Enough," New Republic 88:1142 (21 October 1936), 324-25; Eda Lou Walton, "New Poems by Miss Taggard," New York Times (23 May 1937), 116; and more recently, Marjorie Perloff, "Janus-Faced Blockbuster" [review of Cary Nelson (ed.), Anthology of Modern American Poetry (New York: Oxford University Press, 2000) ], Symploke 8:1-2 (2000), 205-213.

2 Janet McCann, "Genevieve Taggard," Dictionary of Literary Biography, v.45, ed. Peter Quartermain (Detroit: Gale Research, 1986) 376.

3 The author is grateful to Dr. Craig Howes for this important point. See also Maenette K.P.A Benham and Ronald H. Heck, Culture and Educational Policy in Hawai $i$ : The Silencing of Native Voices (New York \& London: Routledge, 1998); and Cecil K. Dotts and Mildred Sikkema, Challenging the Status Quo: Public Education in Hawai'i I 840-1980 (Honolulu: Hawai'i Education Association, 1994).

${ }^{4}$ Richard Hofstadter, The Progressive Movement I900-19I5 (Englewood Cliffs, NJ: Prentice-Hall, 1963) 4-6.

${ }^{5}$ James H. Garrison, "The State of the Cause," Christian-Evangelist XXXI (6 December 1894) 774 .

${ }^{6}$ He sent copies of a magazine called The Progressive Educator to every teacher in the islands. It was printed by the Lahaina educator, Osmer Abbott, who also produced the monthly magazine for schools, called Hawaii's Young People, which was used as a teaching aid by Genevieve's parents.

${ }^{7}$ During one period of their residence in Hawai' $i$, the Taggards lived in the summer home of Governor Walter Frear and his wife Mary Dillingham Frear at Pearl Harbor.

Mrs. Frear was a popular Honolulu poet whose works appeared regularly in Paradise of the Pacific and Mid-Pacific Magazine during Genevieve's high school years, and her encouragement was acknowledged in the preface to Origin: Hawaii.

${ }^{8}$ Flora J. Cooke, "Colonel Francis W. Parker," The Elementary School Teacher 1 2:9 (May 1912) 397-420;398.

9 Barbara Levine, compiler, "Chronology of John Dewey's Life and Work," CronologiaDewey PDF online. Dewey was a friend of George P. Castle, of Mānoa, through their friend in common George Herbert Mead, and he stayed with the Castles on this visit.

${ }^{10}$ John Dewey, "My Pedagogical Creed," The School Journal 65:3 (16 January 1897), 77-8o, <infed.org/mob/john-dewey-my-pedagogical-creed $>$.

${ }^{11}$ Mary Charlotte Alexander and Charlotte Peabody Dodge, Punahou 1841-1941 (Berkeley \& Los Angeles: University of California Press, 1941) 439-40.

12 Philip S. Foner, Jack London: American Rebel, (Berlin: Seven Seas Publishers, 1958) 14, 22.

${ }^{13}$ He was, contradictorily, even more passionately committed to the struggle for socialism, and in his writings and speeches for the socialist movement he dropped the issue of race and addressed all men as comrades. Foner, Jack London, 55 . 
14 "Poet out of Pioneer," The Nation (19 January 1927) 63-64.

${ }_{15}$ Christian Science Monitor (4 December 1920). The series was published November 27, 29, 30; December 2, 4, 6, 8. Her notes in the Genevieve Taggard Papers at Dartmouth College suggest she also intended to write pieces on poinciana, bougainvillea, plumeria, and hibiscus.

${ }^{16}$ Jack London, "My Hawaiian Aloha," Cosmopolitan Magazine 6o-61 (1916); repr. Charmian London, The New Hawaii (London: Mills and Boon, 1923) 9-59; 39.

17 Taggard, "Genevieve Taggard," Twentieth Century Authors, ed. Stanley J. Kunitz \& Howard Haycraft (New York: H.W. Wilson, 1942) 1380-81.

18 "Hawaiian Sonnet" was included in The Poets of the Future: A College Anthology for $1915-16$, and "Maui of Haleakala" appeared as "Solar Myth" in Hawaiian Hilltop (1923).

19 "Little Hawaii in San Francisco," The Friend (Honolulu) (August 1914) 186-7.

20 Taggard to Harriet Monroe, 3 November 1919, Poetry: A Magazine of Verse Records, $1895^{-1961}$, Special Collections Research Center, University of Chicago Library. In 19oo, the area of Kalihi in which they lived was adjacent to sugar, rice and taro fields.

21 Taggard, "Kaiulani in London," New York Evening Post (18 December 1920) 6.

22 After a two-year amalgamation with Workers Monthly, it was re-formed as New Masses in 1926. The poems were "To a Hawaiian Girl" (March 1919); "The Tourist" (August 1919); "Hawaiian Volcano" (October 1920); "To a Hawaiian Playmate" (May 1921); and "Tropic Mother's Melody" (June 1921). It has been suggested that Taggard was a contributing editor on this magazine, but her name does not appear in the editorial credits.

${ }^{23}$ See her poem, "To the League of Dead Nations," Liberator 3 (March 1919), 10.

24 Taggard, "A Haole Scrapbook" (Chapters from Unwritten Autobiographies), Bookman (June 1924) 391-99. The illustrations are by Lydia Gibson, a leftist artist and poet who was published in The Liberator at the same time as Taggard, and who would later marry the communist cartoonist-illustrator of The Masses, Robert Minor.

25 Taggard, "A Haole Scrapbook," 399.

${ }^{26}$ Taggard, introduction, May Days: An Anthology of Verse from Masses-Liberator, ed. Genevieve Taggard (New York: Boni \& Liveright, 1925) 1-15.

27 Taggard, "For Hawaii Brought Low," American Review 3:2 (March-April 1925) 142. Reprinted with the permission of Judith Benét Richardson.

${ }^{28}$ Cecil K. Dotts and Mildred Sikkema, 39.

${ }^{29}$ Clifford Gessler, Hawaii: Isles of Enchantment (New York and London: D. Appleton-Century, 1942): for Taggard's poem see p.131, for Gessler's discussion of plantation conditions and strikes, pp. 308-319. Dartmouth College, the beneficiary of Taggard's book collection upon her death, holds a copy of this book, which is very likely to have come from her library.

${ }^{30}$ Hawaii: A Story of Imperialist Plunder is available online from the Hathi Trust Digital Archive.

31 The issue of Native Hawaiian population at contact is controversial and ongoing. Some scholars now estimate that the Native Hawaiian population at the 
point of contact by Captain Cook in 1778 may have been as large as 800,000 and by 1900 the U.S. Census reported a total of $37,65^{6}$ persons of "full or partial native Hawaiian ancestry," suggesting that Native Hawaiian depopulation may have been even more extreme than in Weinman's version. "Native Hawaiians," <en.wikipedia.org>. See also Robert C. Schmitt, "A Brief Statistical History of Hawai 'i” HJH vol. 37 (2003), and "How Many Hawaiians Live in Hawai'i?" Pacific Studies 19:3 (September 1996), 31-35; and David E. Stannard, Before the Horror, Honolulu: Social Science Research Institute, University of Hawai'i, 1989.

${ }^{32}$ Samuel Weinman, "Librarian's Hawaii," New Masses 11:11 (12 June 1934), 23.

33 Taggard, "Report on Hawaii" ("Readers Forum"), New Masses (2 June 1942) 25-26. [Review of Blake Clark, Remember Pearl Harbor! (1942)] Taggard will have been interested to see that Clark, a teacher at the University of Hawai 'i, was at that time residing at "Arcadia," the home of her family friends, former Governor and Mrs. Frear.

34 "Plenty Pilikia," Yale Review 35:1 (September 1945) 48-6o.

${ }^{35}$ One of the committed activists of this local labor movement, John Reinecke, had also been a poet in the 1920 s, and one of his poems, "Dead at Eleven," was published in Taggard's journal, The Measure (May 1926).

36 T. Michael Holmes, The Specter of Communism in Hawai'i (Honolulu: University of Hawai'i Press, 1994) 24-25.

${ }^{37}$ Strand to Taggard, 13 August 1946, Taggard Papers, New York Public Library. (Hereafter given as Taggard Papers, NYPL.)

38 Taggard to Angus, 15 August 1945, Donald Angus Papers, Hamilton Library Special Collections, University of Hawai'i at Mānoa. (Hereafter given as Angus Papers, HLSC, UH.) Although the poems are described on the title page as having been "selected and published" by Angus, it is clear throughout their correspondence that the decisions on the inclusion of individual works were made collaboratively, and that the poet herself usually had the final word. Fourteen poems from Hawaiian Hilltop were used, plus eleven others, published elsewhere from 1918-1943, and three new poems on Hawaiian subjects, written in 1946: "The Luau," "Pacific," and "Concerning the Possessive Wonders of a Childhood."

${ }^{39}$ He offered it because she had told him about writing her poem "Pacific" after reading his letter with the returning sailors' reports of the horrors of war at sea. Angus to Taggard, 16 May 1946, Angus Papers, HLSC, UH.

${ }^{40}$ Reprinted with the permission of Judith Benét Richardson. First published as "Fructus" in Poetry Quarterly (London), Winter 1946-47, with a text slightly revised for publication in Origin: Hawaii (Honolulu: D. Angus: Printed by the Honolulu Star Bulletin, 1947) where the typography of the final sentence appears in bold rather than in italics, which I render here in roman.

${ }^{41}$ Reprinted with the permission of Judith Benét Richardson.

42 Taggard to Angus, 14 October 1946, Angus Papers, HLSC, UH.

${ }^{43}$ Taggard to Marcia Durant Liles, n.d., [c.1947], Taggard Papers, NYPL.

${ }^{44}$ Alta Taggard to Genevieve, 24 November 1946, Taggard Papers, NYPL. 
